\title{
Pembelajaran Autentik dalam Menulis Teks Deskripsi
}

\author{
Nurul Dwi Lestari \\ nurul.bind@gmail.com \\ Universitas Negeri Malang, Jalan Semarang 5 Malang
}

\begin{abstract}
Abstrak
Kreativitas menjadi salah satu keterampilan penting yang harus dimiliki generasi $Z$ untuk hidup di Abad XXI. Keterampilan menulis kreatif teks deskripsi perlu diperhatikan untuk melatih kepekaan siswa dalam menggambarkan objek berdasarkan pengalaman inderawi. Penelitian ini bertujuan untuk mendeskripsikan pembelajaran autentik (authentic learning) dalam mengembangkan keterampilan menulis kreatif teks deskripsi.Adapun tujuan khusus dalam pembahasan ini adalah mendeskripsikanpembelajaran autentik sebagai pemicu berpikir kreatif dalam menulis teks deskripsi, langkah menulis kreatif teks deskripsi dengan pembelajaran autentik, dan penilaian keterampilan menulis kreatif teks deskripsi.
\end{abstract}

Kata kunci: pembelajaran, autentik, menulis kreatif, teks deskripsi

\section{PENDAHULUAN}

Pada pembelajaran bahasa Indonesia, terdapat empat keterampilan yang perlu dikuasai siswa, yaitu keterampilan menyimak, berbicara, membaca, dan menulis. Menurut Nurgiyantoro (2001:296), kemampuan menulis lebih sulit dikuasai dibandingkan keterampilan berbahasa lainnya, bahkan oleh penutur bahasa yang bersangkutan sekalipun.Salah satu keterampilan menulis yang perlu ditingkatkan, yaitu keterampilan menulis teks deskripsi. Kepekaan siswa dalam menggambarkan objek, peristiwa, hingga suasana perlu ditingkatkan agar teks deskripsi yang dihasilkan memenuhi kaidah yang baik dan benar, detil sesuai yang tertangkap oleh pancaindera sehingga mampu membuat pembaca ikut merasakan objek atau peristiwa yang dideskripsikan, meskipun tidak menyaksikannya secara langsung. Hal ini sesuai dengan pernyataan Priyatni (2014:72) yang menyebutkan bahwa teks deskripsi memaparkan suatu objek/hal/keadaan sehingga pembaca seolah-olah merasakan pengalaman inderawi penulis.

Berdasarkan studi pendahuluan yang dilakukan peneliti di SMP Negeri 1 Grogol, ditemukan informasi bahwa pembelajaran menulis teks deskripsi masih berupa penugasan sederhana. Siswa masih mengalami kesulitan menemukan topik tulisan sehingga objek dan lingkungan yang dideskripsikan pun terbatas pada lingkungan sekolah. Teks deskripsi yang dihasilkan siswa kurang mengeksplor lebih mendalam tentang objek/hal/peristiwa yang dideskripsikan. Masih banyak siswa yang belum mampu mencurahkan ide-idenya ke dalam bentuk tertulis. Dalam pembelajarannya, siswa tidak diberikan tugas-tugas yang kompleks dan menantang untuk memacu mereka berpikir kritis dan kreatif dalam menulis. Akibatnya, hal unik dan baru mengenai objek yang dideskripsikan belum dituangkan ke dalam tulisan.

Dewasa ini, kreativitas dibutuhkan untuk menghadapi tantangan Abad XXI. Menurut Maxwell (2004:136), berpikir kreatif berarti memikirkan apa yang telah dipikirkan semua orang sehingga individu tersebut mampu mengerjakan apa yang belum pernah dikerjakan oleh semua orang. Berpikir kreatif terletak pada inovasi yang membantu diri sendiri untuk mengerjakan hal-hal lama dengan cara yang baru. Dalam menulis teks deskripsi dibutuhkan pemikiran kreatif agar tulisan yang dihasilkan mengandung kebaruan dan inovasi berupa ide, cara berpikir yang berbeda, unik, dan inovatif dari pemikiran yang sudah ada. 


\section{Nurul Dwi Lestari}

Pembelajaran autentik (authentic learning)merupakan pendekatan pembelajaran dengan menghadirkan kondisi riil atau konkret sehingga proses pembelajaran lebih efektif karena siswa dapat mengamati, melihat, melakukan, merasakan, dan menyimpulkan sendiri. Menurut Hennessy dan Murphy (1999), kegiatan autentik yang berhasil adalah yang terkait dengan pembelajaran yang menarik dan mendorong hal-hal yang secara pribadi bermakna bagi siswa dan terarah dari sudut pandang masyarakat. Wiggins mengemukakan bahwa pembelajaran autentik memperbolehkan peserta didik untuk mempelajari dunia nyata menggunakan high order thinking skills (Blank \& Harwell, 1997). Berpikir kreatif termasuk dalam berpikir tingkat tinggi (C6) versi Taksonomi Bloom, yaitu kemampuan mencipta. Pembelajaran autentik diharapkan dapat meningkatkan keterampilan siswa dalam menulis kreatif teks deskripsi.

Mengingat pentingnya keterampilan berpikir kreatif diterapkan untuk pembelajaran menulis teks deskripsi, oleh karena itu dibutuhkan pendekatan pembelajaran yang mampu memotivasi siswa untuk berpikir kreatif. Pembelajaran autentik menjadi salah satu pendekatan pembelajaran yang dapat merangsang siswa aktif menyelidiki masalah atau konteks "nyata" dalam kehidupan siswa. Melalui aktivitas autentik ini, siswa dituntut berpikir kreatif. Tujuan umum dalam penelitian ini, yaitu mendeskripsikan pembelajaran autentik dalam upayanya meningkatkan keterampilan berpikir kreatif siswa dalam menulis teks deskripsi. Tujuan khusus dalam penelitian ini, meliputi (1) mendeskripsikan pembelajaran autentik sebagai pemicu berpikir kreatif dalam menulis teks deskripsi, (2) langkah menulis kreatif teks deskripsi dengan pendekatanauthentic learning, dan (3) peranan pembelajaran autentik dalam memicu ide kreatif siswa.

\section{Pembelajaran Autentik (Authentic Learning)}

Istilah autentik didefinisikan sebagai asli, benar, dan nyata. Pembelajaran autentik berarti pembelajaran yang dilakukan dengan cara dan di tempat yang relevan dengan "nyata" dalam kehidupan peserta didik, baik di dalam maupun di luar kelas. Donovan, Bransford \& Pallegrino (1999:35) menyebutkan bahwa pembelajaran autentik(authentic learning) adalah sebuah pendekatan pembelajaran yang memungkinkan siswa menggali, mendiskusikan, dan membangun secara bermakna konsep-konsep dan hubungan-hubungan, yang melibatkan masalah nyata dan proyek yang relevan dengan siswa. Sejalan dengan itu, Jonassen, Howland, Marra, \& Crismond (2008) menyatakan bahwa pembelajaran autentikmerupakan pembelajaran yang terintegrasi secara mulus atau ditanamkan ke dalam makna dan situasi "kehidupan nyata".

Pengintegrasian pembelajaran melalui konteks yang "nyata" atau relevan bagi peserta didik perlu diterapkan dalam pembelajaran menulis karangan. Hakim (2008:15) menyatakan bahwa menulis merupakan upaya mengekspresikan apa yang dilihat, dialami, dirasakan, dan dipikirkan ke dalam bahasa tulisan. Dalam pembelajaran menulis teks deskripsi, misalnya, siswa melakukan pengamatan terhadap objek-objek yang menarik bagi mereka, kemudian menuliskan apa yang dilihat, didengar, dan dirasakan terkait objek. Pembelajaran autentik memberikan kesempatan bagi siswa untuk menggali informasi yang relevan mengenai suatu objek sehingga mereka memperoleh pengalaman belajar yang bermakna. Dengan begitu, kemampuan mereka dalam menuangkan ide kreatif dapat ditumbuhkembangkan.

Newmann \& Wehlege (1993) menyebutkan bahwa pembelajaran yang autentik adalah pembelajaran yang mencapai "arti dan kebermaknaan", berbeda dengan sesuatu yang "sepele dan tidak berguna". Terdapat tiga kriteria untuk mengidentifikasi instruksi autentik, yaitu (1) siswa membangun makna dan menghasilkan pengetahuan; (2) siswa menggunakan penyelidikan untuk membangun makna; dan (3) siswa menghasilkan wacana, produk, dan pertunjukan yang memiliki nilai atau arti melebihi keberhasilan di sekolah. Instruksi tersebut memiliki kesamaan jika diterapkan dalampembelajaran menulis teks deskripsi yang perlu diawali kegiatan penyelidikan terhadap objek. Instruksi autentik dalam pembelajaran menulis teks deskripsi, yaitu siswa mengamati objek atau peristiwa yang menarik bagi mereka, kemudian menggali informasi mengenai objek tersebut 
berdasarkan pengalaman inderawi. Hasil pengamatan kemudian dituangkan ke dalam sebuah tulisan yang disusun sedemikian rupa supaya menarik untuk dibaca.

Jika bahan atau materi yang disajikan kepada siswa tidak autentik, kurang kontekstual, atau tidak menyajikan situasi yang "nyata" dalam kehidupan peserta didik, maka siswa akan mengalami kesulitan dalam menggali ide dan kemampuan mereka dalam menulis kreatif.Menurut Pranoto (2011), dalam menulis kreatif, pembaca terkagum bukan karena kebenaran, logika, dan fakta, melainkan pada kebenaran artistik yang ukurannya adalah kepekaan intuitif. Berdasarkan pernyataan tersebut dapat ditarik kesimpulan bahwa kepekaan intuitif siswa perlu dirangsang dalam menulis kreatif. Untuk membantu mereka mengembangkan daya imajinasi dan meluaskan fantasi, salah satunya dengan menyajikan konteks dan situasi "nyata" ketika menulis.

Lombardi (2007:2) menyebutkan bahwa pembelajaran autentik memiliki beberapa karakteristik kunci, meliputi (1) belajar adalah berpusat pada tugas-tugas autentik yang menarik bagi peserta didik; (2) siswa terlibat dalam eksplorasi dan penyelidikan; (3) belajar paling sering adalah interdisipliner; (4) belajar sangat erat hubungannya dengan dunia di luar dinding kelas; (5) siswa menjadi terlibat dalam tugas-tugas kompleks dan order kemampuan berpikir lebih tinggi, seperti menganalisis, sintesis, merancang, memanipulasi, dan mengevaluasi informasi; (6) siswa menghasilkan produk yang bisa dibagi dengan pemirsa di luar kelas; (7) belajar bersifat aktif dan digerakkan oleh siswa sendiri, sedangkan guru, orangtua, dan narasumber bersifat membantu atau mengarahkan; (8) guru menggunakan strategi scaffolding, dan (9) siswa memiliki peluang untuk interaksi sosial.

Pembelajaran autentik didasarkan pada konsep "belajar dengan melakukan". Melalui pembelajaran ini diciptakan lingkungan belajar yang "bergerak" yang memungkinkan siswa berperan aktif. Investigasi yang menantang merupakan hal yang sangat penting dalam pengalaman belajar autentik. Proses investigasi ini harus disesuaikan untuk menciptakan motivasi siswa dalam menggali secara mendalam tujuan pembelajaran yang ingin dicapai (Laur, 2013:4-5). Senada dengan itu, Lombardi (2007:2) menyatakan bahwa pembelajaran autentik biasanya berfokus pada masalah dunia nyata, kompleks dan solusinya, menggunakan latihan bermain peran, aktivitas berbasis masalah, studi kasus, dan partisipasi dalam komunitas praktik virtual. Lingkungan belajar secara inheren bersifat multidisiplin. Pembelajaran yang berbasis pada pengalaman belajar autentik berbeda dengan pembelajaran konvensional pada umumnya. Berikut rumusan perbedaannya dalam pembelajaran.

Tabel 1.1 Rumusan Pembelajaran Autentik (Authentic Learning)

\begin{tabular}{|c|c|c|c|}
\hline No & $\begin{array}{l}\text { Aspek yang } \\
\text { Dibedakan }\end{array}$ & Pembelajaran Autentik & $\begin{array}{l}\text { Pembelajaran } \\
\text { Konvensional (Tidak } \\
\text { Autentik) }\end{array}$ \\
\hline 1. & $\begin{array}{l}\text { Konteks / } \\
\text { Lingkungan } \\
\text { Belajar }\end{array}$ & $\begin{array}{l}\text { Melampaui dunia di luar } \\
\text { dinding kelas dan sekolah }\end{array}$ & $\begin{array}{l}\text { Terbatas pada lingkungan } \\
\text { kelas dan sekolah }\end{array}$ \\
\hline 2. & $\begin{array}{l}\text { Aktivitas: } \\
\text { Bentuk Investigasi }\end{array}$ & $\begin{array}{l}\text { Melibatkan investigasi } \\
\text { menantang: } \\
\text { a. Menemukan jawaban } \\
\text { atas suatu persoalan. } \\
\text { b. Menemukan hal unik } \\
\text { yang belum pernah } \\
\text { ditemukan. } \\
\text { c. Mampu mempromosikan } \\
\text { temuan baru pada } \\
\text { khalayak di luar. }\end{array}$ & $\begin{array}{l}\text { Kurang melibatkan aktivitas } \\
\text { investigasi yang } \\
\text { menantang: } \\
\text { a. Siswa kurang dilibatkan } \\
\text { pada aktivitas } \\
\text { menyelidiki. } \\
\text { b. Kalaupun terdapat } \\
\text { penyelidikan, investigasi } \\
\text { yang ditugaskan belum } \\
\text { menantang. }\end{array}$ \\
\hline
\end{tabular}

Mencari Informasi $\quad$ Dalam mencari informasi

Tidak ada inisiatif untuk 


\begin{tabular}{|c|c|c|c|}
\hline & & $\begin{array}{l}\text { tentang suatu objek, siswa } \\
\text { bertanya langsung kepada } \\
\text { ahli. }\end{array}$ & $\begin{array}{l}\text { bertanya kepada ahli } \\
\text { setempat. }\end{array}$ \\
\hline 3. & $\begin{array}{l}\text { Bidang kajian yang } \\
\text { diselidiki }\end{array}$ & $\begin{array}{l}\text { Belajar yang paling sering } \\
\text { adalah mengkaji } \\
\text { interdisipliner artinya ada } \\
\text { interaksi antar lebih dari satu } \\
\text { disiplin ilmu. }\end{array}$ & $\begin{array}{l}\text { Belajar terbatas pada satu } \\
\text { disiplin ilmu. }\end{array}$ \\
\hline 4. & Bentuk Penugasan & $\begin{array}{l}\text { Disajikan tugas-tugas yang } \\
\text { kompleks, rumit, dan } \\
\text { berkelanjutan }\end{array}$ & $\begin{array}{l}\text { Tugas yang disajikan } \\
\text { sederhana dan tidak } \\
\text { berkelanjutan }\end{array}$ \\
\hline 5. & Bentuk Kolaborasi & $\begin{array}{l}\text { Ada kegiatan diskusi } \\
\text { kelompok }\end{array}$ & $\begin{array}{l}\text { Tidak ada kegiatan diskusi } \\
\text { kelompok }\end{array}$ \\
\hline 6. & Strategi guru & $\begin{array}{l}\text { Scaffolding artinya guru } \\
\text { hanya memberikan bantuan } \\
\text { seperlunya saja dan } \\
\text { membiarkan siswa bekerja } \\
\text { secara bebas manakala } \\
\text { mereka sanggup } \\
\text { melakukannya sendiri. }\end{array}$ & $\begin{array}{l}\text { Strategi pembelajaran } \\
\text { konvensional artinya } \\
\text { pembelajaran masih } \\
\text { berpusat pada guru. }\end{array}$ \\
\hline 7. & $\begin{array}{l}\text { Keragaman produk } \\
\text { / hasil tulisan }\end{array}$ & $\begin{array}{l}\text { Produk/hasil tulisan siswa } \\
\text { berdasarkan investigasi } \\
\text { dapat beragam. }\end{array}$ & $\begin{array}{l}\text { Produk/hasil tulisan siswa } \\
\text { sering terjadi kesamaan } \\
\text { atau kurang beragam. }\end{array}$ \\
\hline & Refleksi & $\begin{array}{l}\text { Pebelajar merefleksikan } \\
\text { pembelajaran yang telah } \\
\text { dilakukan dan membuat } \\
\text { pilihan serta target kemudian. }\end{array}$ & $\begin{array}{l}\text { Tidak ada refleksi lebih } \\
\text { lanjut atas pembelajaran } \\
\text { yang telah dilakukan. }\end{array}$ \\
\hline & Penilaian & $\begin{array}{l}\text { Penilaian terpadu dalam } \\
\text { tugas. } \\
\text { Penilaian diintegrasikan } \\
\text { secara mulus dengan } \\
\text { aktivitas. }\end{array}$ & $\begin{array}{l}\text { Hanya ada penilaian akhir } \\
\text { produk }\end{array}$ \\
\hline
\end{tabular}

(Sumber: Artikel berjudul Authentic Learning for the 21st Century: An Overview yang ditulis oleh Lombardi tahun 2007)

Pada pembelajaran autentik, siswa lebih banyak berperan aktif dalam penyelidikan. Guru menggunakan strategi scaffolding artinya guru hanya memberikan bantuan seperlunya saja dan membiarkan siswa bekerja secara bebas manakala mereka sanggup melakukannya sendiri. Menurut Laur (2013:4), dalam pengalaman belajar autentik, seorang guru melepaskan sebagian kontrol terhadap kelas, kemudian menyerahkannya kepada siswa. Dalam pengalaman belajar ini, guru menjadi fasilitator pembelajaran, sementara siswa menjadi "direktur" atau pemimpin dari pengalaman belajar mereka sendiri. Pemberian kebebasan kepada siswa untuk mendapatkan pengalaman belajar yang autentik ini menjadikan mereka memperoleh pengetahuan yang bermakna. Dibandingkan dengan siswa dari pembelajaran tradisional, siswa yang mendapatkan pembelajaran autentik memiliki kinerja belajar lebih baik. Seperti yang diungkapkan Newmann, Bryk dan Nagoka (2001) bahwaterdapat perbedaan kinerja yang signifikan antara siswa yang terpapar dengan tugas kelas yang autentik dan mereka yang diajar dalam cara tradisional. Tidak peduli apa pun kelompok atau latar belakang mereka, para siswa selalu diuntungkan mendapat pengajaran secara autentik di sekolah. 


\section{Langkah Menulis Kreatif Teks Deskripsi}

Menurut Jabrohim (2001:71), kreatif berarti mengajak siswa terbuka dengan pengalamanpengalaman yang baru, keluwesan dalam berpikir, kebebasan dalam pengungkapan pendapat, imajinatif, perhatian yang besar terhadap cipta-mencipta, keteguhan pendapat, perhatian dalam mengajukan pendapat atau pandangan dan yang terakhir kemandirian dalam mengambil keputusan. Menulis kreatif dapat dikatakan sebagai kegiatan menulis dengan menerapkanpemikiran kreatif. Menurut Kurniawan (2014:31), menulis kreatif anak adalah hasil karya penulisan anak yang berupa hasil pengalaman-pengalaman yang berkesan dan menarik bagi anak yang telah dikreasikan dengan fantasi dan imajinasi anak.

Untuk menulis teks deskripsi dibutuhkan kepekaan intuitif siswa dalam meggambarkan objek. Hal itu diperlukan agar teks deskripsi yang dihasilkan menarik untuk dibaca dan mencapai tujuan penulisan teks deskripsi. Imajinasi dan kepekaan intuitif dapat diwujudkan melalui pemilihan topik yang menarik dan unik, penggunaan pilihan kata emotif yang menggugah perasaan pembaca, penggunaan kata kiasan, dan pola pengembangan paragraf deskripsi yang variatif. Seperti yang diungkapkan Hasani (2005:38) bahwa tulisan deskripsi memiliki karakteristik (1) berupaya memperlihatkan detil atau perincian objek, (2) memberi pengaruh sensitivitas dan membentuk imajinatif pembaca, (3) disampaikan dengan gaya memikat dan pilihan kata tepat, (4) lebih banyak memaparkan tentang sesuatu yang dapat didengar, dilihat, dan dirasakan (objeknya pada umumnya berupa benda, alam, warna, manusia), dan (5) organisasi penyampaiannya lebih banyak menggunakan susunan ruang.

Suparno \& Yunus (2008:22) menyebutkan empat langkah menulis karangan deskripsi. Keempat langkah tersebut secara berurutan, meliputi (1) menentukan objek yang akan dideskripsikan, yaitu dengan cara mengamati objek yang akan dideskripsikan, contohnya dengan mengamati hewan dan tumbuhan yang ada di lingkungan sekitar; (2) menetapkan bagian yang akan dideskripsikan, yaitu dengan cara menyajikan informasi tentang objek yang akan dideskripsikan, contohnya deskripsi tentang hewan dan tumbuhan, maka dapat dideskripsikan ciri-ciri fisik, manfaat, dan asal objek tersebut; (3) menyusun rincian bagian yang akan dideskripsikan, yaitu dengan memunculkan kesan dan gambaran yang kuat mengenai suatu objek yang dideskripsikan, contohnya adalah ketika mendeskripsikan tentang hewan maka dapat dideskripsikan ciri-ciri fisik hewan itu, apakah hewan itu berkaki dua, berbulu, memiliki sayap, dapat terbang, dan lain sebagainya; (4) menguraikan rincian bagian yang akan dideskripsikan menjadi tulisan deskripsi sesuai tema dan judul yang ditentukan dengan memperhatikan ejaan dan tanda baca yang benar.

Kegiatan investigasi menjadi komponen sentral dalam pembelajaran autentik. Laur (2013:13) menyatakan bahwa belajar melakukan penyelidikan adalah keterampilan yang dibutuhkan bagi siswa. Guru harus memiliki cara agar keterampilan menyelidiki dikuasai siswa untuk membantu mereka bergerak menemukan informasi. Oleh karena itu, siswa tidak hanya bisa menjadi konsumen informasi, namun juga mampu menjadi produsen informasi baru yang telah dianalisis, dievaluasi, dan diterapkan. Berdasarkan tahapan menulis teks deskripsi dan aspek kemampuan berpikir kreatif yang dikemukakan oleh para ahli di atas, diperoleh rancangan mengenai tahapan menulis kreatif teks deskripsi berbasis pembelajaran autentikyang dipaparkan pada tabel berikut ini.

Tabel 2.1 Tahapan menulis kreatif teks deskripsi berbasis pembelajaran autentik

\begin{tabular}{llll}
\hline No. & \multicolumn{1}{c}{ Sintaks } & \multicolumn{1}{c}{ Aktivitas Autentik Menulis Teks Deskripsi } & \multicolumn{1}{c}{$\begin{array}{c}\text { Kemampuan } \\
\text { Berpikir Kreatif }\end{array}$} \\
\hline 1. & Menentukan & - Mencari objek & Berpikir orisinal \\
& objek yang akan & - Memilih/menentukan objek & Kriteria ide: \\
& dideskripsikan & Contoh: & a. Kebaruan \\
& Tempat : Tastiest Cafe & b. Bernilai \\
& Menu : pizza bromo & c. Unik \\
& & d. Kejutan \\
\hline
\end{tabular}




\begin{tabular}{|c|c|c|c|}
\hline 2. & $\begin{array}{l}\text { Mengamati } \\
\text { objek }\end{array}$ & $\begin{array}{l}\text { Mengamati objek-objek penting yang hendak } \\
\text { dideskripsikan }\end{array}$ & - \\
\hline \multirow[t]{2}{*}{3.} & $\begin{array}{l}\text { Mengidentifikasi } \\
\text { objek }\end{array}$ & $\begin{array}{l}\text { Mengidentifikasi secara umum: nama resto/cafe, } \\
\text { lokasi, menu-menu unggulan } \\
\text { (bahan identifikasi umum) } \\
\text { Contoh: } \\
\text { Nama cafe : Tastiest Cafe } \\
\text { Lokasi : Jalan Borobudur, Malang } \\
\text { Menu unggulan : bromo volcano pizza, } \\
\text { sweet pizza, wagyu beef steak }\end{array}$ & - \\
\hline & & $\begin{array}{l}\text { Mengidentifikasi objek secara khusus: yang mau } \\
\text { dideskripsikan, misalnya menu-menu (makanan dan } \\
\text { minuman) yang tersedia, tata ruang, suasana, } \\
\text { sarana penunjang (wifi) }\end{array}$ & - \\
\hline \multirow[t]{2}{*}{4.} & Membuat peta & Membuat peta isi sesuai dengan objek & - \\
\hline & konsep & Merinci setiap bagian dari objek & Berpikir terperinci \\
\hline \multirow[t]{4}{*}{5.} & $\begin{array}{l}\text { Menilai dan } \\
\text { mempersepsi } \\
\text { bagian-bagian } \\
\text { dari objek }\end{array}$ & $\begin{array}{l}\text { Mempersepsi/menilai menu 1: boxing chicken } \\
\text { Contoh: } \\
\text { Menu boxing chicken yang gurih saya rekomendasi } \\
\text { untuk dicicipi pertama kali. }\end{array}$ & Berpikir evaluatif \\
\hline & & $\begin{array}{l}\text { Mempersepsi/menilai menu 2: green emotion } \\
\text { Contoh: } \\
\text { Menu lain yang wajib disantap adalah green } \\
\text { emotion. Minuman segar ini cocok dinikmati di kala } \\
\text { cuaca terik. }\end{array}$ & Berpikir evaluatif \\
\hline & & $\begin{array}{l}\text { Mempersepsi/menilai tata ruang } \\
\text { Contoh: } \\
\text { Selain masakan yang nikmat, konsep tata ruangnya } \\
\text { juga membuat nyaman. }\end{array}$ & Berpikir evaluatif \\
\hline & & $\begin{array}{l}\text { Mempersepsi/menilai suasana } \\
\text { Contoh: } \\
\text { Pavilion Resto \& Cafe yang berlokasi di Jalan KH } \\
\text { Ahmad Dahlan No. } 70 \text { Relukbetung Bandar } \\
\text { Lampung ini mengedepankan suasana alam yang } \\
\text { sejuk. }\end{array}$ & Berpikir evaluatif \\
\hline 6. & $\begin{array}{l}\text { Menulis teks } \\
\text { deskripsi melalui } \\
\text { penilaian/kesan } \\
\text { dari tiap bagian }\end{array}$ & $\begin{array}{l}\text { Mendeskripsikan hasil penilaian menu 1: boxing } \\
\text { chicken } \\
\text { Contoh: } \\
\text { Menu boxing chicken yang gurih saya rekomendasi } \\
\text { untuk dicicipi pertama kali. Menu dari olahan daging } \\
\text { ayam ini disajikan di atas alas yang bisa dimakan } \\
\text { juga. Masakan ini terbuat dari daging ayam goreng } \\
\text { yang diselimuti tepung panir berbentuk sarung tinju. }\end{array}$ & Berpikir terperinci \\
\hline
\end{tabular}




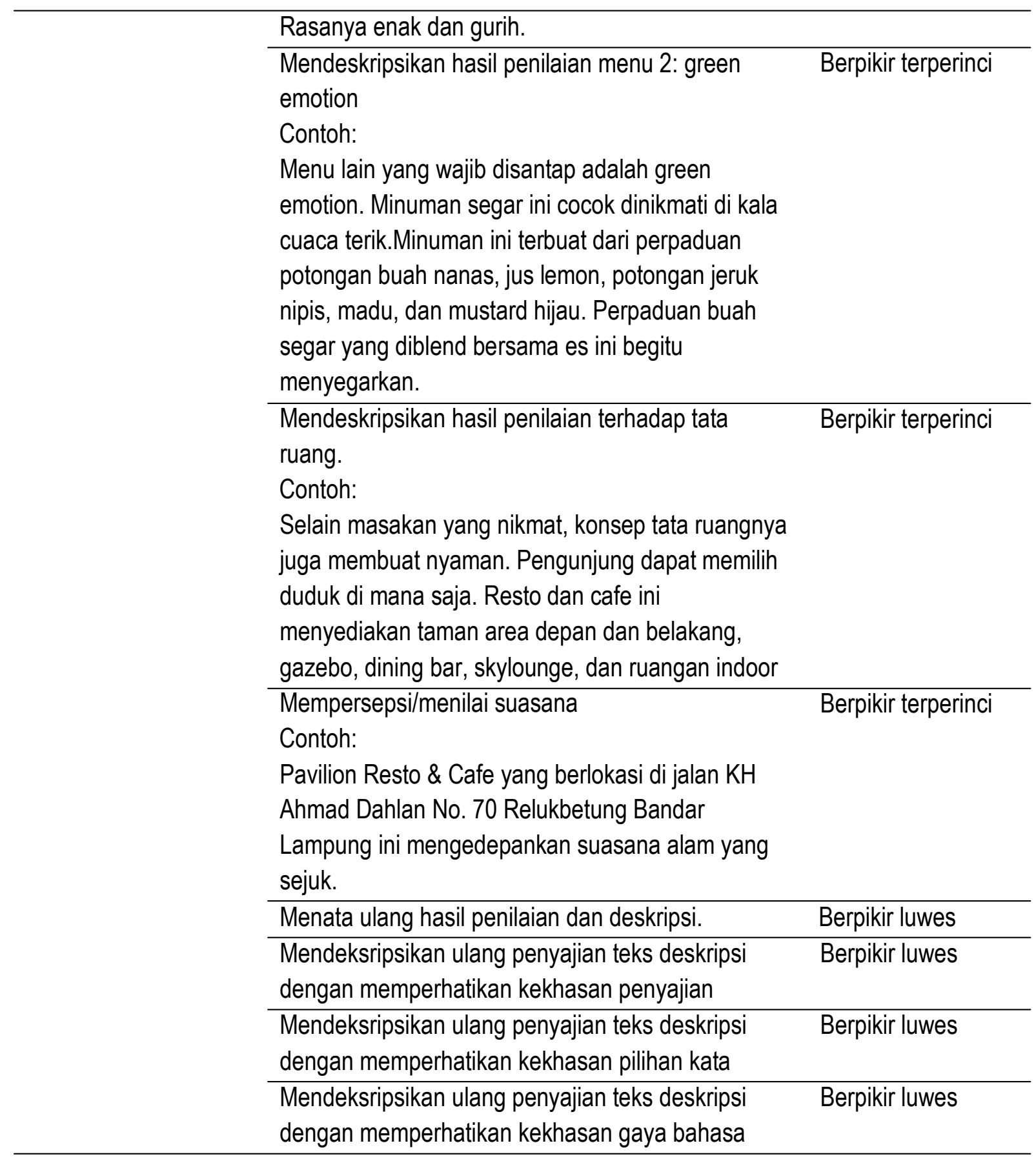

\section{Penilaian Keterampilan Menulis Kreatif Teks Deskripsi}

Perubahan pola pikir paradigma pendidikan saat ini tidak hanya menuntut adanya perubahan dalam proses pembelajaran, tetapi juga perubahan dalam melaksanakan penilaian. Pembelajaran autentik yang diterapkan dalam keterampilan menulis kreatif teks deskripsi tentu memiliki pedoman penilaian yang dapat mengukur kemampuan siswa dalam berpikir kreatif.Menurut Cropley \& Cropley (2000), terdapat tiga jenis tes untuk mengukur kreativitas, yaitu melalui pengukuran aspek proses kreatif, karakteristik kepribadian kreatif, dan aspek produk. yang kemampuan berpikir kreatif siswa dapat dilihat melalui hasil tulisan. Untuk mengukur keterampilan berpikir kreatif siswa dalam menulis teks deskripsi dapat dilakukan melalui aspek produk, yaitu berupa teks deskripsi. Basemar \& O'Quin (1987) menyebutkan bahwa terdapat tiga kriteria suatu produk dikategorikan sebagai produk kreatif, yaitu (1) mempunyai unsur kebaruan (novelty), (2) mempunyai unsur pemecahan (resolution), dan (3) 
mempunyai unsur elaborasi (elaboration) \& sintesis (synthesis). Dalam bukunya, Basemar (2005) merevisi kriteria ketiga menjadi style (bentuk).

Seseorang yang kreatif dapat dilihat dari keterampilan dan sikap yang ditunjukkan ketika mengerjakan sesuatu. Munandar (2009:21) mengemukakan bahwa terdapat beberapa ciri-ciri berpikir kreatif, meliputi (1) keterampilan berpikir lancar, yaitu mampu mencetuskan banyak gagasan, jawaban, penyelesaian atau pertanyaan, memberikan banyak cara atau saran untuk melakukan berbagai hal, selalu memikirkan memikirkan lebih dari satu jawaban; (2) keterampilan berpikir luwes (fleksibel), yaitu mampu menghasilkan gagasan, jawaban atau pertanyaan yang bervariasi, dapat melihat masalah dari sudut pandang yang berbeda-beda, mencari banyak alternatif atau arah yang berbeda-beda, mampu mengubah cara pendekatan atau cara pemikiran; (3) keterampilan berpikir orisinil (kebaharuan), yaitu mampu melahirkan ungkapan yang baru dan unik, memikirkan cara yang tidak lazim untuk mengungkapkan diri, mampu membuat kombinasi yang tidak lazim; (4) keterampilan memerinci (mengelaborasi), yaitu mampu memperkaya dan mengembangkan suatu gagasan atau produk, menambahkan atau memerinci detil-detil dari suatu objek, gagasan, atau situasi sehingga lebih menarik; (5) keterampilan menilai (mengevaluasi), yaitu menentukan patokan penilaian sendiri dan menentukan apakah suatu pertanyaan benar, suatu rencana sehat ataukah suatu tindakan bijaksana, mampu mengambil keputusan terhadap situasi yang terbuka, tidak hanya mencetuskan gagasan, tetapi juga melaksanakannya.

Teks deskripsi menjadi salah satu jenis teks yang dalam penyusunannya membutuhkan keterampilan berpikir kreatif karena membutuhkan kepekaan intuitif dan daya imajinasi penulis tatkala menggambarkan objek. Berdasarkan karakteristik teks deskripsi, kriteria berpikir kreatif, dan ciri-ciri berpikir kreatif yang dikemukakan para ahli di atas dapat dirumuskan indikator untuk mengukur kemampuan menulis kreatif teks deskripsi.Berikut rubrik dan deskriptor penilaian kemampuan berpikir kreatif siswa dalam menulis deskripsi yang digunakan sebagai pedoman penilaian.

Tabel 3.1 Rubrik Penilaian Kemampuan Berpikir Kreatif Siswa dalam Menulis Deskripsi

\begin{tabular}{|c|c|c|c|c|c|c|}
\hline \multirow{2}{*}{ No. } & \multirow{2}{*}{ Aspek yang Dinilai } & \multicolumn{5}{|c|}{ Skor } \\
\hline & & 1 & 2 & 3 & 4 & 5 \\
\hline 1. & Kelancaran (Fluency) & & & & & \\
\hline 2. & Keluwesan (Flexibility) & & & & & \\
\hline 3. & Keaslian (Originality) & & & & & \\
\hline 4. & Berpikir terperinci (Elaboration) & & & & & \\
\hline 5. & Berpikir evaluatif (Evaluation) & & & & & \\
\hline
\end{tabular}

Tabel 3.2 Deskriptor Penilaian Kemampuan Berpikir Kreatif Siswa dalam Menulis Deskripsi

\begin{tabular}{cclc}
\hline Aspek yang Dinilai & Skor & \multicolumn{1}{c}{ Deskriptor } & Kualitas \\
\hline Kelancaran (Fluency) & 5 & Hasil karangan deskripsi siswa menunjukkan & Sangat lancar \\
& & kelancaran jika dalam waktu 80 menit jumlah & \\
& kata yang digunakan dalam karangan lebih dari & \\
& & 200 kata. & \\
\cline { 2 - 4 } & & Hasil karangan deskripsi siswa menunjukkan & Lancar \\
& kelancaran jika dalam waktu 80 menit jumlah & \\
& kata yang digunakan dalam karangan antara & \\
& 150 -199 kata. & \\
\end{tabular}


Nurul Dwi Lestari

\begin{tabular}{|c|c|c|c|}
\hline & 3 & $\begin{array}{l}\text { Hasil karangan deskripsi siswa menunjukkan } \\
\text { kelancaran jika dalam waktu } 80 \text { menit jumlah } \\
\text { kata yang digunakan dalam karangan antara } \\
\text { 100-149 kata. }\end{array}$ & Cukup lancar \\
\hline & 2 & $\begin{array}{l}\text { Hasil karangan deskripsi siswa menunjukkan } \\
\text { kelancaran jika dalam waktu } 80 \text { menit jumlah } \\
\text { kata yang digunakan dalam karangan antara 50- } \\
99 \text { kata. }\end{array}$ & Kurang lancar \\
\hline & 1 & $\begin{array}{l}\text { Hasil karangan deskripsi siswa tidak } \\
\text { menunjukkan kelancaran jika dalam waktu } 80 \\
\text { menit jumlah kata yang digunakan dalam } \\
\text { karangan kurang dari } 50 \text { kata. }\end{array}$ & Tidak lancar \\
\hline \multirow[t]{5}{*}{ Keluwesan (Flexibility) } & 5 & $\begin{array}{l}\text { Hasil karangan deskripsi siswa menunjukkan } \\
\text { keluwesan jika terdapat keberagaman dalam } \\
\text { struktur kalimat yaitu dapat berupa kombinasi } \\
\text { kalimat (1) sederhana, gabungan, dan } \\
\text { kompleks, atau (2) panjang kalimat (kalimat } \\
\text { singkat kurang dari lima kata, kalimat panjang } \\
\text { lebih dari sepuluh kata). Jika terdapat keluwesan } \\
\text { dalam konten atau gagasan yang meliputi } \\
\text { penggunaan (1) kata-kata sifat yang khusus, (2) } \\
\text { pola pengorganisasian, (3) kesan penulis. }\end{array}$ & Sangat luwes \\
\hline & 4 & $\begin{array}{l}\text { Hasil karangan deskripsi siswa menunjukkan } \\
\text { keluwesan jika memenuhi } 4 \text { kriteria. }\end{array}$ & Luwes \\
\hline & 3 & $\begin{array}{l}\text { Hasil karangan deskripsi siswa menunjukkan } \\
\text { keluwesan jika memenuhi } 3 \text { kriteria. }\end{array}$ & Cukup luwes \\
\hline & 2 & $\begin{array}{l}\text { Hasil karangan deskripsi siswa menunjukkan } \\
\text { keluwesan jika memenuhi } 2 \text { kriteria. }\end{array}$ & Kurang luwes \\
\hline & 1 & $\begin{array}{l}\text { Hasil karangan deskripsi siswa tidak } \\
\text { menunjukkan keluwesan jika hanya } 1 \text { atau tidak } \\
1 \text { pun yang memenuhi kriteria. }\end{array}$ & Tidak luwes \\
\hline \multirow[t]{5}{*}{ Keaslian (Originality) } & 5 & $\begin{array}{l}\text { Hasil karangan deskripsi siswa menunjukkan } \\
\text { keaslian, meliputi (1) kebaruan ide, (2) } \\
\text { bernilai/bermanfaat, (3) keunikan objek, (4) } \\
\text { kejutan, (5) relevan }\end{array}$ & Sangat asli \\
\hline & 4 & $\begin{array}{l}\text { Hasil karangan deskripsi siswa menunjukkan } \\
\text { keaslian jika memenuhi } 2 \text { kriteria. }\end{array}$ & Asli \\
\hline & 3 & $\begin{array}{l}\text { Hasil karangan deskripsi siswa menunjukkan } \\
\text { keaslian jika memenuhi } 3 \text { kriteria. }\end{array}$ & Cukup asli \\
\hline & 2 & $\begin{array}{l}\text { Hasil karangan deskripsi siswa menunjukkan } \\
\text { keaslian jika memenuhi } 2 \text { kriteria. }\end{array}$ & Kurang asli \\
\hline & 1 & Hasil karangan deskripsi siswa tidak & Tidak asli \\
\hline
\end{tabular}


Nurul Dwi Lestari

\begin{tabular}{|c|c|c|c|}
\hline & & $\begin{array}{l}\text { menunjukkan keaslian jika hanya memenuhi } 1 \\
\text { atau tidak satu pun kriteria. }\end{array}$ & \\
\hline \multirow[t]{5}{*}{$\begin{array}{l}\text { Berpikir terperinci } \\
\text { (Elaboration) }\end{array}$} & 5 & $\begin{array}{l}\text { Mampu merinci secara detil objek yang } \\
\text { dideskripsikan, mencakup aspek tempat (posisi, } \\
\text { arah), ukuran (berat, volume, jarak), } \\
\text { bentuk/pola, warna, tekstur, nama bahan/alat, } \\
\text { fungsi, nilai, dan kosakata teknis lainnya. }\end{array}$ & Sangat rinci \\
\hline & 4 & $\begin{array}{l}\text { Mampu merinci secara detil } 4 \text { aspek terkait } \\
\text { objek yang dideskripsikan. }\end{array}$ & Rinci \\
\hline & 3 & $\begin{array}{l}\text { Mampu merinci secara detil } 3 \text { aspek terkait } \\
\text { objek yang dideskripsikan. }\end{array}$ & Cukup rinci \\
\hline & 2 & $\begin{array}{l}\text { Mampu merinci secara detil } 2 \text { aspek terkait } \\
\text { objek yang dideskripsikan. }\end{array}$ & Kurang rinci \\
\hline & 1 & $\begin{array}{l}\text { Mampu merinci hanya satu atau tidak satu pun } \\
\text { aspek terkait objek yang dideskripsikan. }\end{array}$ & Tidak rinci \\
\hline \multirow[t]{5}{*}{$\begin{array}{l}\text { Berpikir Evaluatif } \\
\text { (Evaluation) }\end{array}$} & 5 & $\begin{array}{l}\text { Mampu memberikan penilaian objek melalui } \\
\text { kesan panca indera (penglihatan, pendengaran, } \\
\text { penciuman, pengecap, perabaan, dan } \\
\text { perasaan). }\end{array}$ & $\begin{array}{l}\text { Sangat } \\
\text { evaluatif }\end{array}$ \\
\hline & 4 & $\begin{array}{l}\text { Mampu memberikan penilaian objek melalui } \\
\text { kesan empat panca indera. }\end{array}$ & Evaluatif \\
\hline & 3 & $\begin{array}{l}\text { Mampu memberikan penilaian objek melalui } \\
\text { kesan tiga panca indera. }\end{array}$ & $\begin{array}{l}\text { Cukup } \\
\text { evaluatif }\end{array}$ \\
\hline & 2 & $\begin{array}{l}\text { Mampu memberikan penilaian objek melalui } \\
\text { kesan dua panca indera. }\end{array}$ & $\begin{array}{l}\text { Kurang } \\
\text { evaluatif }\end{array}$ \\
\hline & 1 & $\begin{array}{l}\text { Mampu memberikan penilaian objek melalui } \\
\text { kesan satu atau tidak satu pun panca indera. }\end{array}$ & $\begin{array}{l}\text { Kurang } \\
\text { evaluatif }\end{array}$ \\
\hline
\end{tabular}

(Diadaptasi dari Munandar, 2009)

Berdasarkan deskriptor penilaian kemampuan berpikir kreatif dalam menulis teks deskripsi di atas, dapat diperoleh gambaran bahwa dalam setiap indikator terdapat lima komponen. Setiap butir yang memenuhi syarat diberi skor 1 sehingga skor tertinggi yang bisa diperoleh untuk masing-masing indikator adalah 5. Penilaian berpikir kreatif ini terdiri atas lima indikator sehingga skor tertinggi yang dapat diperoleh siswa adalah 15.Berdasarkan perolehan skor pada tiap-tiap indikator, maka dapat ditentukan tingkat kemampuan berpikir kreatif siswa dalam menulis teks deskripsi. Kriteria penjenjangan tingkat kemampuan berpikir kreatif dalam menulis teks deskripsi ditunjukkan dalam tabel berikut.

Tabel 3.3 Tingkat Kemampuan Berpikir Kreatif Siswa dalam Menulis Teks Deskripsi

\begin{tabular}{ll}
\hline \multicolumn{1}{c}{ Tingkat } & \multicolumn{1}{c}{ Karakteristik } \\
\hline $\begin{array}{l}\text { Tingkat 5 (Sangat } \\
\text { kreatif) }\end{array}$ & $\begin{array}{l}\text { Jika siswa mampu menunjukkan lima kemampuan berpikir kreatif, } \\
\text { mencakup kelancaran, keluwesan, keaslian, elaboration, dan evaluatif. }\end{array}$ \\
\hline Tingkat 4 (Kreatif) & Jika siswa mampu menunjukkan empat kemampuan berpikir kreatif. \\
\hline Tingkat 3 (Cukup kreatif) & Jika siswa mampu menunjukkan tiga kemampuan berpikir kreatif. \\
\hline Tingkat 2 (Kurang & Jika siswa mampu menunjukkan dua kemampuan berpikir kreatif. \\
\hline
\end{tabular}


kreatif)

Tingkat 1/0 (Tidak Jika siswa mampu menunjukkan hanya satu atau tidak satupun kemampuan kreatif) berpikir kreatif.

(Diadaptasi dari Rhosalia, Laksono, \& Sukartiningsih, 2016:170)

\section{DAFTAR RUJUKAN}

Besemer, S.P. 2005. Be creative!, using creative product analysis in gifted education, Creative Learning Today, 13, 4, 1-4.

Besemer, S.P., \& O'Quin, K. (1987). Creative product analysis: Testing a model by judging instrument, In S.G. Isaken (ed), Frontier of Creativity Research: Beyond the Basic, Bufallo, New York: Bearly.

Blank, W. 1997. Authentic Instruction. Dalam Blank \& S.Harwell (Eds.), Promising Practices for Connecting High School to the Real World (hlm. 15-21). Tampa, FL: University of South Florida.

Cropley, D.H., \& Cropley, A.J. 2000. Fostering Creativity in Engineering Undergraduate, High Ability Studies, 12, 2.

Donovan, M.S., Bransford, J.D., \& Pellegrino, J.W. (Eds). 1999. How People Learn: Bridging Research and Practice. Washington, DC: National Academy Press.

Hakim, M.A. 2008. Kiat Menulis Artikel di Media dari Pemula Sampai Mahir. Bandung: Nuansa.

Hasani, A. 2005. Ikhwal Menulis. Serang: Universitas Sultan Ageng Tirtayasa Press.

Hennessy, S., \& Murphy, P. (1999). The potential for collaborative problem solving in design and technology. International Journal of Technology and Design Education, 9 (1), 1-36.

Jabrohim, dkk. 2001. Cara Menulis Kreatif. Yogyakarta: Pustaka Pelajar.

Jonassen, D., Howland, J., Marra, R.M., \& Crismond, D. 2008. Meaningful Learning with Technology (3rd ed.). Upper Saddle River: Pearson Education, Inc.

Kurniawan, H. 2014. Pembelajaran Menulis Kreatif. Bandung: Remaja Rosdakarya.

Laur, D. 2013. Authentic Learning Experiences: A Real-World Approach to Project-Based Learning. London: Routledge.

Lombardi, M.M. 2007. Authentic Learning for the 21st Century: An Overview. Educause. (Online), (http://www.Imi.ub.edu/cursos/s21/REPOSITORIO/documents/Lombardi_2007_Authentic_learni ng.pdf) diakses 15 Oktober 2017.

Maxwell, J.C. 2004. Berpikir Lain Dari Yang Biasanya (Thinking for A Change). Batam: Karisma Press.

Munandar, U. 2009. Pengembangan Kreativitas Anak Berbakat. Jakarta: Rineka Cipta.

Newmann, F.M., \& G.G Wehlege. 1993. Five Standards of Authentic Instruction. Educational Leadership, 50 (7): 8-12.

Newmann, F., Bryk, A. S., \& Nagaoka, J. K. 2001. Authentic Intellectual Work And Standardized Tests: Conflict Or Coexistence? Improving Chicago's Schools. Chicago: Consortium on Chicago School Research.

Nurgiyantoro, B. 2001. Menulis secara Populer. Jakarta: Pustaka Jaya.

Pranoto, N. 2011. Creative Writing. Jakarta: Primamedia Pustaka. 
Nurul Dwi Lestari

Priyatni, E.T. 2014a. Desain Pembelajaran Bahasa Indonesia dalam Kurikulum 2013. Jakarta: PT. Bumi Aksara.

Rhosalia, L.U., Laksono, K., Sukartiningsih, W. 2016. Kemampuan Berpikir Kreatif dalam Menulis Naratif Siswa Kelas V Sekolah Dasar Negeri di Kecamatan Gayungan Surabaya. Jurnal Review Pendidikan Dasar: Jurnal Kajian Pendidikan dan Hasil Penelitian, 2 (2): 166-174.

Suparno \& Yunus. 2008. Keterampilan Dasar Menulis. Jakarta: Universitas Terbuka. 